This item was submitted to Loughborough's Research Repository by the author.

Items in Figshare are protected by copyright, with all rights reserved, unless otherwise indicated.

\title{
'Black and whiters': the relative powerlessness of 'active' supporter organization mobility at English Premier League football clubs
}

PLEASE CITE THE PUBLISHED VERSION

http://dx.doi.org/10.1080/14660970.2014.891988

\section{PUBLISHER}

(C) Taylor \& Francis

\section{VERSION}

AM (Accepted Manuscript)

\section{PUBLISHER STATEMENT}

This work is made available according to the conditions of the Creative Commons Attribution-NonCommercialNoDerivatives 4.0 International (CC BY-NC-ND 4.0) licence. Full details of this licence are available at: https://creativecommons.org/licenses/by-nc-nd/4.0/

\section{LICENCE}

CC BY-NC-ND 4.0

\section{REPOSITORY RECORD}

Cleland, Jamie, and Kevin Dixon. 2019. '“black and Whiters': The Relative Powerlessness of 'active' Supporter Organization Mobility at English Premier League Football Clubs". figshare. https://hdl.handle.net/2134/17897. 


\section{'Black and whiters': The relative powerlessness of 'active' supporter organization mobility at English Premier League football clubs}

This article examines the reaction by Newcastle United supporters to the resignation of Kevin Keegan as Newcastle United manager in September 2008. Unhappy at the ownership and management structure of the club following Keegan's departure, a series of supporter-led meetings took place that led to the creation of Newcastle United Supporters' Club and Newcastle United Supporters' Trust. This article draws on a non-participant observation of these meetings and argues that although there are an increasing number of 'active' supporters throughout English football, ultimately it is the significant number of 'passive' supporters who hamper the inclusion of supporters' organizations at higher-level clubs. The article concludes by suggesting that clubs, irrespective of wealth and success, need to recognize the long-term value of supporters. Failure to do so can result in fan alienation and ultimately decline (as seen with the recent cases of Coventry City and Portsmouth).

\section{Keywords: fans; Premier League; supporter clubs; inclusion; mobilization}

\section{Introduction}

Over the last twenty years there have been many changes to English football. In this postHillsborough era, the most significant change has been the introduction of a Premier League in 1992 and its growing relationship with satellite television (most notably BSkyB). This global exposure has helped increase the number of sponsors and overseas investors and has ultimately changed the nature of supporters. The introduction of all-seater stadiums and increasing ticket prices to help pay for them, for example, created a progressive customercentered approach by clubs who sought to encourage more affluent spectators from outside the traditional, local fan-base to attend matches. $\left[{ }^{1}\right]$ Unhappy at the commercial changes impacting upon football fandom, a number of 'active' fans (defined as those fans who actively participate in the creation as well as exchange of information with other fans, clubs, supporter organizations, groups and the media) began seeking a greater sense of inclusion in the club-fan relationship. This has been helped by the growing media, in particular the Internet and the development of supporter-based websites that also allow fans to actively participate in discussions on message boards and other forums or blogs.

Whilst scholarly work has examined the politicized and active nature of fandom, limited work has actually looked at specific case studies of supporter resistance at English Premier League clubs. $\left[{ }^{2}\right]$ Brown's article looked at the formation of a new club, FC United of 
Manchester, as a form of resistance to the takeover of Manchester United by the Americanbased Glazer family in 2005 and Williams recent article looked at the creation of a supporter group ('Spirit of Shankly') at Liverpool in 2008 in response to the financial mismanagement of the club by Americans Tom Hicks and George Gillett. $\left[{ }^{3}\right]$ Although not on a global scale as Liverpool or Manchester United, the focus of this article is on the response of supporters towards the English-based owner of Newcastle United, Mike Ashley, immediately after the resignation of Kevin Keegan as Newcastle United manager in September 2008.[ $\left.{ }^{4}\right]$

During Keegan's eight-month tenure (he had previously managed the club between 1992 and 1997), a management structure had been adopted where the transfer policy was the responsibility of a "football-related" executive director (Dennis Wise) and a "vice-president of player recruitment” (Tony Jimenez). Frustrated by his lack of input into player recruitment, Keegan resigned and was quoted as saying: 'It's my opinion that a manager must have the right to manage and that clubs should not impose upon any manager any player that he does not want'.[ $\left.{ }^{5}\right]$ Almost immediately, an impromptu meeting was held by active Newcastle United fans. From this emotive gathering a further two meetings were held, and out of this emerged an organized fan group 'Newcastle United Supporters' Club' (NUSC) that subsequently became ‘Newcastle United Supporters’ Trust' (NUST).

The purpose of this article is to examine the series of meetings that led to the creation of NUSC and NUST and provide a comparative analysis on the extent to which active participation leads to a greater form of supporter inclusion within top-level English football clubs. It shall provide a timely update from the work of Nash who examined (amongst other clubs) the Independent Newcastle United Supporters Association (INUSA) after its creation in 1994 to campaign for a better relationship between the club and its supporters.[ ${ }^{6}$ ] According to Nash, even when controversy occurred in 1998 involving the then chairman, Freddy Shepherd, and his deputy, Douglas Hall, the number of members of INUSA only 
reached 600 and led to him concluding that 'INUSA has not been able to penetrate the highly commercial Newcastle United at all’.[ $\left.{ }^{7}\right]$

In spite of the creation of NUSC and NUST, the article will argue that, for English club-supporter relations at least, only when clubs (usually those in the lower-leagues) face financial problems does supporter inclusion become an alternative that clubs are willing to engage with (such as with the recent examples of Northampton Town and Portsmouth). Although Newcastle United supporters were actively seeking greater levels of inclusion, the lack of supporter engagement across the club's wider and 'passive' fan base (defined as those fans that do not actively engage with other fans, clubs, supporters organizations and the media) ultimately detracts from the impact supporter resistance like this can actually achieve. Likewise, the globalization and commodification of the Premier League and the significant financial outlay needed to acquire enough shares has also been detrimental to supporter inclusion at Premier League clubs.

\section{Background}

Since the legalization of professionalism by the Football Association in 1885 and the need to charge fans an entrance fee to pay players' wages, fans have been a key stakeholder in the game. $\left[{ }^{8}\right]$ For 100 years, fans were often excluded by clubs despite many running into financial difficulty, where only public and private donations from supporters and the local community kept many of them in business. $\left[{ }^{9}\right]$ As suggested by Cleland, fans watching football before the 1980s had two options in the form of a protest: (a) either 'vote with their feet' and stay away, or (b), join a post-match demonstration. $\left[{ }^{10}\right]$ Rising hooliganism and dilapidated stadia led to attendances declining from 41.2 million in 1948 to 16.3 million in 1986, but there were other reasons why a large number of supporters stopped attending matches (such as increasing home ownership, more disposable income and an interest in other activities outside of football). $\left[{ }^{11}\right]$ 
Those fans that remained were critical to the survival of the game, but it was not until the 1980s that fans actually became more active in their involvement within football. At this time, football was a prominent feature of political arguments as evidence of the social decline of the United Kingdom (UK) and the disasters and violence that marred the sport did not help change this national image. The frequent reporting of acts of violence at football matches reached its nadir in May 1985 when, at the European Cup Final at Heysel, Brussels, the behavior of Liverpool fans caused the death of 39 Juventus fans. $\left[{ }^{12}\right]$ The immediate reaction by the game's governing bodies was to ban English clubs from European competition and led to the then Prime Minister, Margaret Thatcher, to initially propose the use of ID cards for fans to carry with them when attending matches. This was the catalyst for some supporters to act upon this negative portrayal and initially led to the development of print fanzines where supporters had a platform to feel included by sharing their ideas and fears about the game. $\left[{ }^{13}\right]$ The availability of what Crawford refers to as 'cultural texts' allowed fans to develop their own identities in the context of their football life (Nick Hornby's widely-acclaimed Fever Pitch; a book that tracked his life as an Arsenal supporter is a case in point) and this has been advanced further with the introduction of the Internet and the opportunity to both create and/or contribute to club-specific blogs and websites. $\left[{ }^{14}\right]$

Cultural changes like this not surprisingly led to scholars creating typologies to explain modern fandom from the 1980s onwards. Most of this was based around the rise of the service sector after the UK went through a period of de-industrialization that resulted in a reduction in the industrial working classes and expanded the number of white-collar workers. This changing demographic of the workforce and growth in consumer society, for Redhead, led to 'participatory' or 'active' supporters that helped create and develop fanzines and supporter organizations.[ $\left.{ }^{15}\right]$ Outside of the active role played by supporters, Giulianotti argues that these societal changes created two classifications of fandom: 'traditional' (those 
who attend regularly and have emotional ties to a particular club) or 'consumer' (those who do not live near the ground and might follow a particular team via television or other forms of media). $\left[{ }^{16}\right]$ This was a result of the commodification of football since the introduction of the Premier League in 1992 and subsequent creation of marketing and/or commercial departments at clubs where fans became referred to as 'consumers' (rather than be seen purely as a 'traditional' fan). These changes had obvious implications for the culture of football as a wider fan demographic became a target for clubs to attract into football.

The use of fan dichotomies by scholars has been criticized by Williams, who argues that scholars have exaggerated the decline of traditional notions of fandom and underplayed the importance of continuity, place and community in their cultural and social practice. $\left[{ }^{17}\right]$ Indeed, Gibbons and Dixon suggest that traditional fan practice has been helped by new media as it allows football to be consumed through various means (such as everyday communication available via message boards and blogs on the Internet as well as the broadcasting and coverage given to football by television). $\left[{ }^{18}\right]$ However, as suggested by Cleland, a significant number of passive fans remain and this is detrimental to the overall inclusion of supporter organizations and groups at some of the bigger English clubs. $\left[{ }^{19}\right]$

As well as the individual nature of resistance like those conducted by fanzine editors, a more collective resistance also emerged out of the way football fans were portrayed during the violent period of the 1980s. The creation of the Football Supporters' Association three months after the Heysel disaster in 1985 led the way in establishing more localized independent fan movements that sought opportunities for the closer involvement of fans in the decision-making process of football clubs. $\left[{ }^{20}\right]$ This localized active supporter resistance escalated dramatically during the 1990s where the aforementioned changes to English football led to the formation of an Independent Supporters' Association (ISAs) at a number of clubs. $\left[{ }^{21}\right]$ Summarizing the culture of football for fans during the 1990s, Lee states how it had 
become 'an increasingly expensive, passive and individualistic experience' and ISAs challenged football's modernization (notably around stadium redevelopment, ticket prices, crowd demography) by attempting to re-define and democratize the relationship between fans and clubs. $\left[{ }^{22}\right]$ For King and Nash, this was a direct result of the increasing tension many traditional working-class supporters felt towards more affluent, newer 'consumer' ones, who it was argued did not attach the same social attachment towards 'their' club, but were willing to pay the increasing cost of tickets in order to watch Premier League football. $\left[{ }^{23}\right]$

Whilst ISAs continue to serve a valuable purpose, one of the biggest changes to the club-fan relationship came when the then Labour government established an initiative called Supporters Direct in 2000 that encouraged supporters to get involved in promoting corporate governance. $\left[{ }^{24}\right]$ With the aim of forging 'a new relationship between supporters, their clubs and the local community', $\left[{ }^{25}\right]$ for those active supporters who wanted to become involved in the day-to-day running of a particular club, legal and practical assistance was available to establish a democratic Supporters' Trust where the acquisition of club shares would allow supporter representation on the board of directors. The first prominent Supporters' Trust was at Northampton Town after the club fell into administration in 1992 and resulted in the Trust raising money and accruing enough shares to have supporter representation on the board of directors. $\left[{ }^{26}\right]$ Highlighting the continued success of the Trust movement at lower-level clubs, the latest example of a successful Supporters' Trust is at Portsmouth. After becoming the first club in the history of the Premier League to enter administration in 2010, Portsmouth entered administration again in 2012 and remained this way for 14 months until Portsmouth Supporters’ Trust raised $£ 3$ million in pledges (fans were asked to donate $£ 1,000$ ) and the administrator accepted this offer to take over the club in April 2013.[ $\left[{ }^{27}\right]$

In the majority of cases like this, the inclusion of Supporters' Trusts have been a success, but they often tell their own story - when a club falls into financial difficulty the 
onus is on the supporters to help rescue it. $\left[{ }^{28}\right]$ Indeed, from what we have seen so far with Supporters' Trusts, they are more likely to have a significant impact at the lower-level of professional football than the top-level where major corporate finance is required to purchase a large number of shares. $\left[{ }^{29}\right]$ Although there has been some success of supporter involvement at other clubs (such as Exeter City, AFC Wimbledon, Wrexham and Wycombe Wanderers), for the higher-level clubs commercialization has often taken precedence over the relationship with supporters, and as a result it is not surprising that there have been decisions that seek to exploit commercial revenues even further. The club under review in this article, Newcastle United, is one such example where some of its supporters have recent experience of being alienated. The offer to buy bonds to help pay for the post-Hillsborough ground redevelopments was meant to guarantee supporters the right to purchase a season ticket in their allocated seat every year. Despite over 7,000 supporters thinking this offer was indefinite, a section of them were contacted by the club in 1999 to highlight how a previously unmentioned contractual point actually allowed the club to build corporate hospitality boxes where their seat used to be. $\left[{ }^{30}\right]$ Another striking example of alienation is the re-location by Wimbledon from Selhurst Park in London to Milton Keynes (a stadium located 56 miles away). This bitter dispute led to the establishment of a Supporters' Trust at Wimbledon who argued that 'their' club had been stolen from them and resulted in a new team, AFC Wimbledon, and a mass boycott of the re-named MK (Milton Keynes) Dons.

Perhaps the most high-profile example of supporter alienation, however, is the Glazer takeover at Manchester United in 2005. Already disgruntled at media giant BSkyB's failed takeover of the club for $£ 643$ million in 1998 , the decision to sell the club to the American businessman, Malcolm Glazer, led to significant locally-based protests that culminated in the creation of a new democratically-run football club, FC United of Manchester and a protest campaign 'Green and Gold' emerging in early 2010. The clear feeling of the importance of 
FC United of Manchester to its immediate community was stressed by the mission of the club to 'maintain or re-establish the community' and to be 'an example of how to bring football back to ordinary people'.[ $\left.{ }^{31}\right]$ A more recent football-related social movement includes the 'Spirit of Shankly' group set up by Liverpool fans in 2008 in the wake of the financial mismanagement of the club by its then American owners, Tom Hicks and George Gillett, who had purchased the club in 2007 (it became clear that despite their denials, they too had adopted a Glazer-type leveraged buyout of the club) and had burdened the club with a large debt (reportedly over $£ 400$ million). $\left[{ }^{32}\right]$ However, foreign capital is not always contested, as Millward found that fans of Manchester City actually welcome the investment being made by its owner, Sheikh Mansour bin Zayed al-Nahyan, because of the chance to gain immediate success. $\left[{ }^{33}\right]$

\section{Method}

For geographical purposes, one of the authors attended the three meetings that arose after the resignation of Kevin Keegan in 2008. The date (September 16, 2008) and location of the initial public meeting (all three meetings were held in The Irish Center - approximately 500 meters away from the Gallowgate End of Newcastle United's ground, St. James’ Park) was announced in two predominant Newcastle United fanzines: 'The Mag' and 'True Faith'. This initial meeting was used to judge support for a new supporters' group (NUSC) as well as its potential structure, and allowed fans to put themselves forward to represent the group in various roles. The second meeting (February 4, 2009) updated fans on the progress of NUSC, its committee and provided an opportunity for attendees to air their views about the future direction of the group. In the third public meeting (March 19, 2009), the main part of the agenda was to outline the intention of NUSC to change its status to that of a Supporters' Trust in order to seek a way of including supporters in the decision making process at Newcastle United. Members of NUSC were joined on stage by guest speakers from 
'Supporters Direct' and members of another Trust set up by supporters at Lincoln City (NUST was officially launched in October 2009).

Given the size of the club and its place in the Premier League, it was not surprising that local and national media attended and reported on the meetings. $\left[{ }^{34}\right]$ Writing on the 'corrosive lack of communication between the club and their supporters', for example, Caulkin argued in The Times that the club remained more 'bullish than appeasing'.[ $\left.{ }^{35}\right]$ Moreover, writing in the Daily Mirror, Bird referred that the club’s hierarchy should have attended the meetings:

\footnotetext{
'Listening. Learning. Getting connected with some of the club's most passionate, intelligent, concerned fans....all Newcastle fans want is a well-run club. Where they are listened to. Where they feel the hierarchy are regularly communicating with them. $\left[{ }^{36}\right]$
}

To accommodate those fans that could not attend in person, the last two meetings were broadcast over the Internet, but all three meetings were well attended. At meetings one and two, the function room, upstairs in the Irish Center, was over capacity (numbers were approximately 250-300), with approximately 150 people attending the third meeting. The demographic of the crowd was mixed, but did contain children with parents, young men and women (aged 16-40) as well as older men and women (aged 40 and above). While there were more males than females, women were significantly represented and actively took part in all discussions.

Permission was given by the chair of these meetings to record the discussions taking place and this was further validated by the presence of local and national media also recording and commenting on the discussions. Throughout the meetings a non-participant observation was undertaken as it is an unobtrusive method that is unlikely to change the behavior of the participants. $\left[{ }^{37}\right]$ It is worth noting however, that given the average attendance of Newcastle United is over 45,000, this article makes no claim to be representative of all of the club’s supporters; rather, it examines those that actively engaged in the meetings and the 
level of inclusion they ultimately gained. Despite this limitation, the data does capture the active nature of some supporters and the resistance showed towards the management and governance of a well-supported Premier League club.

In analyzing the transcripts of the three meetings, both authors went through the data separately to examine for patterns, commonalities and differences across the responses taken from each meeting. $\left[{ }^{38}\right]$ Through this inductive approach, the open-ended data was broken down into larger theoretical categories and consistent themes then began to emerge. What shall now be presented is an analysis of discussions captured within the meetings, the eventual outcome of these meetings and a comparative analysis of the level of impact and inclusion of supporter organizations at higher-level clubs like the ones created at Newcastle United.

\section{The Initial Meetings}

There are many similarities with what was found through the observation of the Newcastle United supporters meetings and what Millward and Williams raise from the creation of the 'Spirit of Shankly’ fan group at Liverpool during 2008.[ $\left[{ }^{39}\right]$ Both, for example, were attended by hundreds of supporters (mainly men, but by fans of all ages) where the social and cultural meaning of the club was paramount in the discussions that took place. In his analysis of supporter unrest at Liverpool, for example, Williams states how it was important for the locally-based Liverpool fans setting up 'Spirit of Shankly' that it had 'cultural assimilation into the club's prized and acutely Scouse textures, cultures and traditions'. $\left[{ }^{40}\right]$ This theme of local identity, culture and community was also raised by numerous Newcastle United supporters across the meetings and resonates with what Hughson and Free argue about the importance of 'place' in the cultural practice of fandom for supporters. $\left[{ }^{41}\right]$ They suggest that fans relate to the club as a cultural commodity whose meaning depends on fans (or residents of a particular locality) being able to see their own history as supporters. $\left[{ }^{42}\right]$ In this sense, the 
football club is, as Soja would contend, a site for routine mental reflection and emotional investment that lives on in fan consciousness irrespective of the cold reality of ownership.[ $\left.{ }^{43}\right]$ Moreover, Dixon argues that fans are often unable to distinguish between pride in the football club and pride in the town or city associated with it. $\left[{ }^{44}\right]$ Summarizing the role of 'place' as an important part of fandom for local-based supporters, this reaction from two Newcastle United fans was similar to many others heard across all of the meetings:

Ashley is destroying one of the greatest institutions of Newcastle. He is destroying Newcastle in effect. Everybody here bleeds Newcastle United, and Newcastle United is the city of Newcastle. When Newcastle United is on the rise, the city is on the rise. When Newcastle United is on the slump, the city is on the slump...This guy is a parasite. He is destroying this club and he is destroying the reputation of the city.

I have always been staggered that a club Newcastle United's size hasn't had a supporters club for years. The one consistent thing at this club is great support. People care about the club. It is easy to support Manchester United because it is easy to support success, everybody can jump on success, but we support the club of our birth, the club that we've been told about, that we've learned about and we will do it from cradle to grave.

As suggested by Kennedy, supporters like this share a sense of 'moral ownership' of football clubs, but fans are more commercially aware as the financial nature of football becomes more significant in determining success. $\left[{ }^{45}\right]$ For some fans, the tag of 'consumer' is no longer resisted like it once was by ISAs and other supporter organizations in the 1980s and 1990s. In fact, for active fans it has become a potential position of power for future negotiations with club management structures. In the case of the meetings taking place at Newcastle United, a number of fans turned what was once perceived as a negative connotation into a positive one where it was used to actively fight against the perception that Mike Ashley was destroying the club and its cultural identity to thousands of supporters. This was raised by the chairman of the Supporters' Club, Malcolm Shields, when he argued: 'The club needs to be interested in their fans, their customers, who pay for season tickets, pay for strips, buy programmes or whatever'. Even though this was supported by other fans, the tag of 'customer' or 'consumer' was not met with the acclaim of all supporters, with this fan forcefully stating: 'People are fed up to the back teeth of being treated with contempt by the football club and treated as 
customers. We are not customers, we are supporters. If we were customers we would have left to get a better product”. Another supporter concurred:

The club belongs to us morally. It would not exist financially without us, it is actually in the interest of the club to be inclusive... it has got an emotional attachment, it is right in our souls, it is part of our identity, it is what we are, yet we are treated like customers. Actually we are treated worse that customers because there's a dimension because the owner knows we'll never support anyone else...Black and Whiters. It is our responsibility to campaign for that. We have got to try to make it happen and say let's have what is rightfully ours.

The English model of club ownership by one or a few individuals is not matched in some of the football heartlands of Europe. In Germany, for example, fans can become members of clubs, where a 50 per cent plus one rule applies to club ownership that prevents wealthy businessmen from taking control of German clubs. $\left[{ }^{46}\right]$ Therefore, the need for fans like this one to argue: 'In getting representation we are not asking for the world, we are just asking for what's ours', does not apply to the established club-fan relationship that exists in other European countries.

Although the traditional notion of local culture, community and place were significant themes across the meetings, the need for supporters to be collectively active was also overly expressed, as if to remind those present of the importance of the Supporters' Club in representing all Newcastle United supporters:

It is not a talking shop, it is a very active group. I have got a lot of confidence that we can take matters forward... what we need to do is make demands of the club and start making that a little bit more, a testing arena for those at the club... Being active is the key.

Indeed, in the second meeting, Malcolm Shields felt the need to defend the progress the Supporters' Club had made in a short space of time:

We have been accused about not being active enough, but we have had to set things up properly ...We have done all that stuff now - we have got a website, a postal address, a bank account. People are joining daily, our numbers are rising. I think we gave out membership number 850 the other day and we are dealing with 6,000 emails declaring interest. While we won't please everyone there we are seeing from people like yourselves a certain consensus on what we all want.

However, when these numbers were compared to the average number of supporters attending matches at Newcastle United, it provides verbal evidence of the hidden impact of passive 
supporters on the mobility of supporter organizations at higher-level clubs. As Nash found in his research on INUSA in the late 1990s, it should not be assumed that all fans that feel excluded or alienated will appear in protest movements. $\left[{ }^{47}\right]$ 1,000 fans at a lower-league club would have greater significance in capturing the mood of a large percentage of supporters, but at a higher-league club like Newcastle United, these numbers are only a fraction of the supporter base.

\section{The Outcome}

Williams highlights how the early meetings of the 'Spirit of Shankly' group that aimed to force the exit of the then American owners, Tom Hicks and George Gillett, were 'highly politically attuned' and contained a proud 'local Supporters' Union, not a corporatized and bureaucratic Supporters' Trust'.[ $\left.{ }^{48}\right]$ Evidence of a different type of strategy to the one at Liverpool occurred at the third public meeting when a motion was put to Newcastle United supporters about whether NUSC should be set up as a Supporters' Trust. After a show of hands this was supported unanimously amongst those present. Reminding supporters of the importance of establishing NUST, Malcolm Shields stated: 'Our main aim has always been and remains that we think there should be some form of board representation from a fan or fans. That is Newcastle United Supporters' Trust's ultimate aim'. The importance of NUST gaining credibility and ultimately inclusion in the club was also raised by another committee member during the same meeting:

The constitution we have adopted so far is based on the Supporters' Trust. Obviously still Newcastle United Supporters' Club, but if you can constitute yourself under the Supporters' Trust banner with a long-term aim, then I think that would be a good idea for us going forward.

As with the aim of most Supporters' Trusts, NUST sought to 'strengthen the bonds between the clubs and the supporters' as well as 'to promote the full, accountable democratic and constructive involvement of supporters in the running and direction of the club, including the principle of supporter representation on the board'. $\left[{ }^{49}\right]$ To try and encourage more supporters 
to actively become members, another committee member provided an overview of what they would be paying for should they choose to sign up:

The view that I have always had is that the ultimate aim of any supporter organization is not just to protest, I do not want to be a member of just a protest group. What I want is to be involved in a supporters' organization that has a long-term aim for the benefit of supporters and Newcastle United. Whether it be liaising with Ashley or whomever. This means having our foot in the door through the acquisition of club shares.

Even though short-term progress had been made, some supporters took a more long-term view as to the role of the Supporters' Trust once it had been established: 'I think we've got to be pragmatic. We're not going to get rid of Ashley in the short-term'. Indeed, across the recent history of supporter groups, organizations, trusts and clubs, most have been created because of a short-term crisis at a particular club, but the longevity of them suggests some form of long-term focus, whether that be by acquiring shares or gaining some other form of inclusion at the respective club.

Initially the level of supporter unrest did have an immediate effect on Ashley, who put the club up for sale just 10 days after the resignation of Kevin Keegan: 'I have listened to you. You want me out. That is what I am now trying to do but it won't happen overnight and it may not happen at all if a buyer does not come in. $\left[{ }^{50}\right]$ However, in December 2008 he took the club off the market after failing to find an acceptable buyer and stated how he was 'committing to the club as its owner'. $\left[{ }^{51}\right]$ Infuriating fans further by again putting the club on the market and taking it off during 2009, Ashley risked the wrath of fans by changing the historic stadium name of 'St James' Park' to his own company's 'sportsdirect.com @ St James’ Park' until the end of the 2009/10 season for purely commercial reasons.[ $\left.{ }^{52}\right]$

\section{The future of supporter organizations}

Despite the active role played by supporters since the mid-1990s in seeking greater levels of inclusion, most supporters’ organizations involved at clubs at the top-level of English football remain relatively powerless in what they can actually achieve. The primary reason for this is the financial resource needed to purchase a number of shares that allows them some form of 
inclusion in club-related discussions. Although it has been widely reported how NUST is actively looking to buy shares in the club, at the time of writing they remain unsuccessful. $\left[{ }^{53}\right]$ To put this argument into some perspective, even though Manchester United Supporters' Trust (MUST) reportedly has 190,000 members, it has very little influence over the Glazers. As suggested by Herbert, although the Glazers are not loved by Manchester United supporters, 'there is a significant difference between that and outright insurrection. Winning has a habit of silencing a revolution'.[ $\left.{ }^{54}\right]$ However, MUST remain actively involved in representing fans and this can be seen with a recent application to Trafford Council to list the name of the ground, Old Trafford, as an "asset of community value" in order to prevent the name of the ground being sold for commercial gain (like what temporarily happened at Newcastle United). $\left[{ }^{55}\right]$

Whilst a change of owner did occur at Liverpool, (through a forced sale of $£ 300$ million to Boston-based New England Sports Ventures (later becoming Fenway Sports Group) in October 2010), Williams states that it was down to the global economic crisis, rather than local supporter opposition. $\left[{ }^{56}\right]$ Likewise, the lack of supporter inclusion and ultimate power in the club-fan relationship was also raised by Cleland in his analysis of supporter unrest towards the then Aston Villa chairman, Doug Ellis in 2002. $\left[{ }^{57}\right]$ Despite supporters of Aston Villa becoming highly frustrated by the fact that they felt the club was not listening to them, it was only at annual shareholder meetings where the club would respond to questions. For those that were non-shareholders, there was no opportunity to engage in any meaningful debate with senior club officials.

Feelings of powerlessness like this were also raised by Newcastle United supporters, with one supporter illustrating how a previous attempt at creating a Supporters' Trust at the club failed: 'I was involved some years ago in the Supporters' Trust at Newcastle. The problem at the time was that unless you had a foot in the door, some type of foot such as 
shareholding, then the club would never listen to you. I think that's been proved throughout football'. Likewise, this supporter argued: 'On one hand we want rid [of Ashley], but on the other, no-one is prepared to take on the club, so do we try to resurrect the relationship with Ashley, a marriage made in hell? What do we do, it is just a nightmare'.

A common point of discussion across the Newcastle United supporter meetings was the number of fans that called for an immediate short-term boycott of club merchandise and the purchasing of goods (such as beer and food) inside the stadium. 'The only power we have got is as consumers because that is how the club has processed us down the years, just to be people who buy things from them. Not people who are proper supporters or shareholders etc. We are just walking wallets milked with dosh', said one fan, whilst another argued:

I am really concerned about the direction of this group. It is losing its way already. It's alright having a long-term aim (which I agree with), but we have a short-term crisis at this football club...so the boycott is not being observed $100 \%$ but what boycott ever is?

However, the practicality of all supporters adhering to this was quickly realized by more pragmatic supporters: 'I don’t think we could get a boycott back on track no matter what we do. It's people's lives man! They go the game and they have their routines...It's what they have done for years'. Feelings like this outline some of the problems of trying to establish a supporters' organization at a club with a significant passive supporter base. According to Millward, fans 'legitimize' identity by continuing to purchase goods and tickets and the size of Newcastle United is confirmed by the club regularly appearing in the Top 20 Money League published by Deloitte and Touche on European football since the mid-1990s. $\left[{ }^{58}\right]$ Thus, the financial economy of top Premier league clubs and the transnational 'network society' each is involved in hampers the potential impact of any supporter boycott on decisions being made the hierarchy of the club. $\left.{ }^{59}\right]$

Indeed, it was clear from the meetings that even those who deem themselves to be active, do not necessarily want to see change: 'Personally, I am not anti-Mike Ashley at all. In fact I 
am pro Ashley if anything. Now I support NUSC in what they are trying to do in terms of representing the fans but I think it's based on a minority group. I'm not sure that the majority of fans want Ashley out'. Similar views were also shared by this fan:

If you are like me you are not going to allow a situation where you cannot go to the match. I could be in bed with the flu but will still get up to go to the match. I support that team out there. I support the shirt. I don't care who the players are, who the manager is, don't give a shite who owns the club. As long as they put a team out, I'll be there every home game and the majority of away games to cheer them on.

As identified by Williams, the key test for supporters' organizations lies when a sense of normality resumes. $\left[{ }^{60}\right]$ Even though Liverpool got new owners in 2010, Newcastle United has not. Tellingly, Williams states how the new owners of Liverpool have set up an Anfield supporters' committee, but that this 'risks being seen locally as a mechanism for managing consumer dissent more than one for advancing real supporter representation'.[ $\left.{ }^{61}\right]$ There is no sense of inclusion like this at Newcastle United (however little it may be) and provides further evidence of the lack of power of supporter organizations at clubs at the higher-level of English football.

\section{Conclusion}

This article has highlighted how the once passive nature of football fandom is increasingly becoming more active through the creation of supporter groups like the ones at Newcastle United in 2008/09. Developments of social movements like this since the early 1990s should remind clubs about the importance of maintaining a healthy and inclusive relationship with the growing number of active supporters involved at each club. As suggested by Nash:

\footnotetext{
It would indeed be easy to dismiss forms of fan organization as abstract contestation that is yet to effectively shape football's contours, and as powerless and worthless, yet to do so ignores the significance of contestation in itself, as an expression of what certain fans deem central elements of their fandom. The culture of the powerless can be as important as that of the powerful, simply because power is continually in flux. $\left[{ }^{62}\right]$
}

Although on-the-field success ultimately influences the club-fan relationship, Cleland makes a pertinent point when he argues about 'the importance of maintaining a healthy relationship between a club and its supporters is imperative because any risk posed by non-attendance 
would threaten the very existence of any professional club'.[ $\left.{ }^{63}\right]$ The recent case of Portsmouth is an example of how a failure to embrace supporters and include them in discussions can have disastrous consequences. A similar situation is now occurring at Coventry City, who entered administration in March 2013 (with debts reportedly of £60 million) after failing to recover from relegation from the Premier League in 2001. Not only has the club suffered financially as a result, but has also seen attendances drop by over 80 per cent since the club relocated to Northampton's Sixfields Stadium to play its 'home' matches after a dispute with the stadium owners and local council.

The term 'black and whiters' used by one Newcastle United supporter has wider resonance to the lack of involvement supporters have at higher-level clubs. Thus, the results gathered at Newcastle United concur with the thoughts of Nash when he stated 'until fan groups penetrate those club decision-making processes, their value systems will remain largely abstract...and so mostly irrelevant'.[ $\left.{ }^{64}\right]$ With significant numbers of passive supporters attending matches, it presents a greater obstacle in generating membership and collective resistance in supporter organizations than at lower-league teams where there is a greater potential to have an effective influence on key decisions. Of course, clubs at a lowerlevel have to rely on gate receipts a lot more than those in the Premier League, where television revenue remains a significant income stream for a number of clubs and disaffected supporters can be replaced. Therefore, this article has illustrated that despite an increasing number of active supporters seeking to gain better inclusion in Premier League clubs (190,000 members of MUST is evidence of that), the significance of passive supporters' remains and this is unlikely to change any time soon.

\footnotetext{
${ }^{1}$ Brown, 'United We Stand'; Haynes, The Football Imagination; King, The End of the Terraces; Lee, 'Grey Shirts to Grey Suits’; Nash, 'Contestation in Modern English Professional Football’; Redhead, The Passion and the Fashion.

${ }^{2}$ See, for example, Brown, 'United We Stand'; Brown, 'Our Club, Our Rules’; Cleland, 'From Active to Passive’; Millward, The Global Football League; Millward, 'Reclaiming the Kop’; Nash, 'Contestation in
} 
Modern English Professional Football’; Nash, ‘English Football Fan Groups in the 1990s'; Williams, 'Walking Alone Together the Liverpool Way'.

${ }^{3}$ Brown, 'Our Club, Our Rules’; Williams, 'Walking Alone Together the Liverpool Way'.

${ }^{4}$ Ashley began acquiring shares in the club in May 2007 with the initial purchasing of Sir John Hall's 41.6 per cent share. After acquiring Freddy Shepherd's 28 per cent share Ashley was allowed to take full ownership of the club in July 2007. Williams (1996) discusses the role of Sir John Hall in the early 1990s (a majority shareholder at Newcastle United from 1992 to 2007) and how he regarded the club as a symbol of identity in the North-East that could be used to promote international investment into the area of Tyneside, in which Newcastle United is located (and subsequently aid the employment prospects of many Newcastle United fans). Whilst Hall could gain financially from any regional business projects that came into Tyneside, he also focused on improving the long-term profitability of the team, with investment into the playing squad and reconstruction of St James’ Park significant elements of his time as chairman.

${ }^{5}$ BBC Sport, 'Keegan Resigns as Newcastle Boss'.

${ }^{6}$ Nash, 'Contestation in Modern English Professional Football'; Nash, 'English Football Fan Groups in the 1990s'.

${ }^{7}$ Nash, 'English Football Fan Groups in the 1990s', 53. See: BBC News, 'Newcastle Utd Directors Resign’ for an analysis of remarks made by Shepherd and Hall in a newspaper sting by the now defunct Sunday tabloid, News of the World.

${ }^{8}$ Mason, Association Football and English Society.

${ }^{9}$ Taylor, Football and its Fans; Tischler, Footballers and Businessmen; Walvin, The People's Game.

${ }^{10}$ Cleland, 'From Active to Passive'.

${ }^{11}$ Russell, Football and the English.

12 Ibid.

${ }^{13}$ Haynes, The Football Imagination; Jary et al. 'Football "Fanzines” and Football Culture', 581-98.

${ }^{14}$ Crawford, Consuming Sport, 19-52; Dixon, Consuming Football; Hornby, 'Fever Pitch'; Millward, 'The Rebirth of the Football Fanzine'.

${ }^{15}$ Redhead, The Passion and the Fashion.

${ }^{16}$ Giulianotti, 'Supporters, Followers, Fans and Flanéurs'.

${ }^{17}$ Williams, 'Walking Alone Together the Liverpool Way'.

${ }^{18}$ Gibbons and Dixon, 'Surfs Up!'.

${ }^{19}$ Cleland, 'From Active to Passive'.

${ }^{20}$ Russell, Football and the English, 230.

${ }^{21}$ Brown, 'United We Stand'.

${ }^{22}$ Lee, 'Grey Shirts to Grey Suits', 33.

${ }^{23}$ King, The End of the Terraces; Nash, 'Contestation in Modern English Professional Football'.

${ }^{24}$ Hamil et al. The Changing Face of the Football Business; Holt et al. 'The State of the Game'.

${ }^{25}$ Hamil et al. The Changing Face of the Football Business, 7.

${ }^{26}$ Lomax, 'How Democracy Saved Northampton Town FC', 102-10.

${ }^{27}$ BBC Sport, 'Portsmouth: PST Settlement Deal with Portpin Revealed'.

${ }^{28}$ Holt et al. 'The State of the Game'.

${ }^{29}$ Ibid.

${ }^{30}$ Conn, 'Newcastle’s Bond Holders Sacrificed on Alter of Profit'.

31 Brown, 'Our Club, Our Rules'.

${ }^{32}$ Millward, 'Reclaiming the Kop’; Williams, 'Walking Alone Together the Liverpool Way'.

${ }^{33}$ Millward, The Global Football League.

${ }^{34}$ Bird, 'Why Newcastle Fans Deserve More Than Silent Contempt from Mike Ashley and Joe Kinnear';

Caulkin, 'No Let Up in Newcastle Fans Actions against Mike Ashley’; Caulkin, 'Newcastle United in a Sorry State Over Fans'; Gibson, 'NUFC Fans Team Up to Form Supporters Club’; Ryder, 'New Supporters Club to Give Fans a Voice’.

${ }^{35}$ Caulkin, 'Newcastle United in a Sorry State Over Fans'.

${ }^{36}$ Bird, 'Why Newcastle Fans Deserve More Than Silent Contempt from Mike Ashley and Joe Kinnear'.

${ }^{37}$ Bryman, Social Research Methods, 273. Mike Weed (2008) adopted a similar observatory role when he analyzed virtual football spectatorship in a public house during the 2006 football World Cup.

${ }^{38}$ Miles and Huberman, Qualitative Data Analysis.

39 Millward, 'Reclaiming the Kop'; Williams, 'Walking Alone Together the Liverpool Way'.

${ }^{40}$ Williams, 'Walking Alone Together the Liverpool Way', 435.

${ }^{41}$ Hughson and Free, 'Paul Willis, Cultural Commodities and Collective Sport Fandom'. See also, Brown et al. 'Introduction: Football and Community'; Nash, 'Contestation in Modern English Professional Football’ for similar arguments. 
${ }^{42}$ Hughson and Free, 'Paul Willis, Cultural Commodities and Collective Sport Fandom'.

${ }^{43}$ Soja, Thirdspace.

${ }^{44}$ Dixon, Consuming Football.

${ }^{45}$ Kennedy, 'Supporters Direct and Supporters' Governance of Football'.

${ }^{46}$ The reunification of Germany in 1990 allowed for a review of the governance of football in the unified country with fan membership central to the ownership of clubs. This resulted in a minimum ownership model of 50 per cent plus one (although Bayer Leverkusen and Wolfsburg were controlled by external companies the level of ownership by supporters could go up to 100 per cent in German clubs).

${ }^{47}$ Nash, 'Contestation in Modern English Professional Football'.

${ }^{48}$ Williams, 'Walking Alone Together the Liverpool Way', 433.

${ }^{49}$ BBC Sport, 'Fans Bid to Buy Newcastle Share'.

${ }^{50}$ BBC Sport, 'Ashley Puts Newcastle Up For Sale'.

${ }^{51}$ BBC Sport, 'Ashley Calls Off Newcastle Sale'.

${ }^{52}$ Dixon, Consuming Football, 76-77.

${ }^{53}$ BBC Sport, 'Fans Bid to Buy Newcastle Share'.

${ }^{54}$ Herbert, 'Glazers Winning the Battle for Manchester United's Finances, If Not Hearts'.

${ }^{55}$ Ibid. On October 9, 2012, payday loan company Wonga.com became Newcastle United's main commercial sponsor and purchased the stadium naming rights. They subsequently announced that the St James' Park name would be restored as part of the deal.

${ }^{56}$ Williams, 'Walking Alone Together the Liverpool Way'.

${ }^{57}$ Cleland, 'From Active to Passive'.

${ }^{58}$ Millward, The Global Football League.

${ }^{59}$ Ibid.

${ }^{60}$ Williams, 'Walking Alone Together the Liverpool Way'.

${ }^{61}$ Ibid, 439.

${ }^{62}$ Nash, 'Contestation in Modern English Professional Football', 467.

${ }^{63}$ Cleland, 'From Active to Passive', 549.

${ }^{64}$ Nash, 'Contestation in Modern English Professional Football’, 482.

\section{References}

BBC News, 'Newcastle Utd Directors Resign’. BBC News, March 24, 1998.

http://news.bbc.co.uk/1/hi/sport/football/68984.stm

BBC Sport. 'Keegan Resigns as Newcastle Boss'. BBC Sport, September 4, 2008.

http://news.bbc.co.uk/sport1/hi/football/teams/n/newcastle_united/7593683.stm

BBC Sport. 'Ashley Puts Newcastle Up For Sale’. BBC Sport, September 14, 2008.

http://news.bbc.co.uk/sport1/hi/football/teams/n/newcastle_united/7615618.stm

BBC Sport. 'Ashley Calls Off Newcastle Sale’. BBC Sport, December 28, 2008.

http://news.bbc.co.uk/sport1/hi/football/teams/n/newcastle_united/7801792.stm

BBC Sport. ‘Fans Bid to Buy Newcastle Share’. BBC Sport, October 7, 2009.

http://news.bbc.co.uk/sport1/hi/football/teams/n/newcastle_united/8294513.stm

BBC Sport. 'Portsmouth: PST Settlement Deal with Portpin Revealed'. BBC Sport, April 26, 2013.

http://www.bbc.co.uk/sport/0/football/22167299

Bird, S. 'Why Newcastle Fans Deserve More Than Silent Contempt from Mike Ashley and Joe Kinnear'. Daily Mirror, February 5, 2009.

Brown, A. 'United We Stand: Some Problems with Fan Democracy'. In Fanatics! Power, Identity and Fandom in Football, ed. A. Brown. London: Routledge, 1998: 50-68.

Brown, A. ' Our Club, Our Rules': Fan Communities at FC United of Manchester'. Soccer and Society 9, no. 3 (2008): 346-58. 
Brown, A., T. Crabbe. and G. Mellor. 'Introduction: Football and Community - Practical and Theoretical Considerations’. Soccer and Society 9, no. 3 (2008): 303-12.

Bryman, A. Social Research Methods (4 ${ }^{\text {th }}$ edition). Oxford: Oxford University Press, 2012.

Caulkin, G. 'No Let Up in Newcastle Fans Actions against Mike Ashley’. The Times, September 16, 2008.

Caulkin, G. ‘Newcastle United in a Sorry State Over Fans’. The Times, February 9, 2009.

Cleland, J. 'From Passive to Active: The Changing Relationship between Football Clubs and Football Supporters'. Soccer and Society 11, no. 5 (2010): 537-52.

Conn, D. 'Newcastle's Bond Holders Sacrificed on Alter of Profit'. The Independent, October 21, 1999. http://www.independent.co.uk/sport/football/news-and-comment/newcastles-bond-holders-sacrificed-on--altarof-profit-742693.html

Crawford, G. Consuming Sport: Fans, Sport and Culture. London: Routledge, 2004.

Dixon, K. Consuming Football in Late-Modern Life. Aldershot: Ashgate, 2013.

Gibbons, T. and K. Dixon. 'Surfs Up!': A Call to Take English Soccer Fan Interactions on the Internet More Seriously. Soccer and Society 11, no. 5 (2010): 599-613.

Gibson, J. ‘NUFC Fans Team Up to Form Supporters Club’. Evening Chronicle, September 17, 2008.

Giulianotti, R. 'Supporters, Followers, Fans and Flanéurs': A Taxonomy of Spectator Identities in Football'. Journal of Sport and Social Issues 26, no. 1 (2002): 25-46.

Hamil, S., J. Michie, C. Oughton, and S. Warby. The Changing Face of the Football Business: Supporters Direct. London: Frank Cass, 2001.

Haynes, R. The Football Imagination: The Rise of the Football Fanzine Culture. Aldershot: Arena, 1995.

Herbert, I. 'Glazers Winning the Battle for Manchester United's Finances, If Not Hearts'. Independent, April 27, 2013. http://www.independent.co.uk/sport/football/news-and-comment/glazers-winning-the-battle-formanchester-uniteds-finances-if-not-hearts-8590748.html

Holt, M., J. Michie, C. Oughton, and L. Shailer. 'The State of the Game: The Corporate Governance of Football Clubs 2004'. Research Paper No. 3, Football Governance Research Centre. London: Birkbeck, University of London, 2004.

Hornby, N. Fever Pitch. New York: The Berkley Publishing Group, 1992.

Hughson, J. and M. Free. 'Paul Willis, Cultural Commodities and Collective Sport Fandom'. Sociology of Sport Journal 23, no. 1 (2006): 72-85.

Jary, D., J. Horne, and T. Bucke. ‘Football "Fanzines” and Football Culture: A Case of Successful “Contestation”'. Sociological Review 39, 3 (1991): 581-98.

Kennedy, P. 'Supporters Direct and Supporters' Governance of Football: A Model for Europe?’ Soccer and Society 13, no. 3 (2012): 409-25.

King, A. The End of the Terraces: The Transformation of English Football in the 1990s. London: Leicester University Press, 1998.

Lee, S. 'Grey Shirts to Grey Suits: The Political Economy of English Football in the 1990s'. In Fanatics! Power, Identity and Fandom in Football, ed. A. Brown. London: Routledge, 1998: 32-49. 
Lomax, B. 'How Democracy Saved Northampton Town FC'. In The Changing Face of the Football Business: Supporters Direct, ed. S. Hamil, J. Michie, C. Oughton, and S. Warby. London: Frank Cass, 2001: 102-10.

Mason, T. Association Football and English Society 1863-1915. Brighton: Harvester, 1980.

Miles, M. and M. Huberman. Qualitative Data Analysis: A Sourcebook of New Methods. Thousand Oaks: Sage, 1984.

Millward, P. 'The Rebirth of the Football Fanzine: Using E-zines as a Data Source'. Journal of Sport and Social Issues 32, no. 3 (2008): 299-310.

Millward, P. The Global Football League: Transnational Networks, Social Movements and Sport in the New Media Age. Basingstoke: Palgrave, 2011.

Millward, P. 'Reclaiming the Kop: Analysing Liverpool Supporters' Twenty-First Century Mobilisations'. Sociology 46, no. 4, (2012): 633-648.

Nash, R. 'Contestation in Modern English Professional Football: The Independent Supporters Association Movement’. International Review for the Sociology of Sport 35, no. 4 (2000): 465-86.

Nash, R. 'English Football Fan Groups in the 1990s: Class, Representation and Fan Power'. Soccer and Society 2, no. 1 (2001): 39-58.

Redhead, S. The Passion and the Fashion: Football Fandom in New Europe. Aldershot: Avebury, 1993.

Russell, D. Football and the English. Preston: Carnegie, 1997.

Ryder, L. 'New Supporters Club to Give Fans a Voice’. Evening Chronicle, September 15, 2008.

Soja, E.W. Thirdspace: Journeys to Los Angeles and Other Real and Imagined Places. Oxford: Blackwell, 1996.

Taylor, R. Football and its Fans: Supporters and their Relationship with the Game 1885-1985. Leicester:

Leicester University, 1992.

Tischler, S. Footballers and Businessmen: The Origins of Professional Soccer in England. New York: Holmes and Meier, 1981.

Walvin, J. The People’s Game: The History of Football Revisited. Edinburgh: Mainstream, 1994.

Weed, M. 'Exploring the Sport Spectator Experience: Virtual Football Spectatorship in the Pub’. Soccer and Society 9, no. 2 (2008): 189-97.

Williams, J. ‘The New Football in England and Sir John Hall’s New Geordie Nation'. In Football and Regions in Europe, ed. S. Gehrmann. Hamburg: LIT Verlag, 1996: 243-278.

Williams, J. 'Walking Alone Together the Liverpool Way: Fan Culture and 'Clueless' Yanks'. Soccer and Society 13, no. 3 (2012): 426-42. 